\title{
CORPORATE BRANDING EFFECTS ON CONSUMER PURCHASE PREFERENCES IN SERBIAN TELECOM MARKET
}

\author{
Gajo Vanka
}

\begin{abstract}
This research is carried out to know the role of corporate branding in mobile phone network along with different influencing factors involved in the purchase of mobile telephone connections. This paper discusses corporate branding from consumer's point of view that how much they value it and what type of role it has. This is a quantitative study. A questionnaire is used in order to investigate corporate branding and other influencing factors involved in purchase decision of the customers. Population selected for this study are Belgrade University students which is the most of Serbian youth segment and is a valuable source that gives precise information with high probability about market preferences according to the Research of Serbian republic statistical office. Primary data are obtained by collecting data from questionnaire and interview, while the secondary data are collected from various reliable sources. Primary data provide reliable content in accordance with a secondary data obtained by Serbian republic statistical office and with a Research of competitor and consumer preferences insight provided by Telenor Company. The analysis of the data has been performed in accordance with the chosen theories and summarized in a table, which serves as a tool for deriving reliable and relevant conclusions. The sample size was determined by conducting a primary study and defining the variance of primary sample and the intended number of samples was selected carefully and randomly from the population. Then the validity and reliability of the questionnaire was determined. The used questionnaire in this research consisted of 7 common, and 30 specialized questions which were supporting the hypotheses of the research. Data was analyzed using the frequency percent techniques, and in the chapter related to the deductive statistics, one-sample $t$ test was used to analyze and approve/disapprove the questions supporting the research hypotheses. The analysis of this study reveals different set of results while making comparison between literature and empirical. It investigates the relative importance of the corporate branding to the customers in mobile phone telecommunication industry while making purchase decision. The findings of this study provided useful information which is helpful not only for the students but also for the brand managers of mobile telecom operators that how they can improve their company's strategic position for longer period of time through corporate branding to trigger more customers and for a good brand.
\end{abstract}

Key words: Corporate branding, Services \& Quality, Loyalty \& Trust, Price, Switching and Mobile Network service providers

\section{Introduction}

In mobile telecommunication, purchase settings are continuous and different than the purchase settings of retails stores etc (Ranaweera \& Prabhu, 2003). In this industry most of the customers maintain long term relationships with the operators (Ranaweera \& Prabhu, 2003). Where factors like trust, image, and satisfaction are not easy to measure. But also factors like switching are easy to measure because in this industry switching is more than simply walking to another Store. Because it requires considerable time and effort due to the presence of switching barriers and switching decision is made after considerable thought. And most importantly this sector provides an environment of high automation which makes the customers Think Twice before leaving (Ranaweera \& Prabhu, 2003). The linkage between core values and corporate brand is described by a firms brand equity and competitive position (Ozer, 2004). A customer has brand building in his mind through the process of controlled and uncontrolled communication (Ozer, 2004). Today, for every firm a critical question for its success is that how it can maintain its current customers and how it can make them loyal to the brands. Loyal customers pay important role in building businesses by making different moves like buying more, by paying premium prices and most importantly providing companies different sets of new customers by positive word of mouth (Ganesh et. al. referred in Aydin and Ozer, 2004). In fact telecommunication companies lose their customer quite regularly. So it's very challenging task for the mobile phone operators to retain existing customers as well as bringing new customers towards their brands and creating loyalty in them. It happens in almost every industry but especially in telecommunication services, it is said that when customers are connected to a particular service provider or operator then their long term relationship with the operator is of great importance for the success of the company in the competitive market (Gerpott et. al. 2001 referred in Aydin and Ozer 2004). Another factor which is very important in telecommunication industry is price. Price is a very sensitive issue in this industry, which is very dynamic factor in this industry; customers are very price sensitive in this industry. Kay, (2006) argues that brand meanings are incorporated into the lives of consumers so brands are social or cultural property rather than company property. 
This study involves different sections to find out the result of the research. Analysis is one of them with high importance, as it comprise of a comparison between primary data and secondary data. Major problem during the purchase of a particular mobile phone connection is discussed mainly in relation with corporate branding and with other factors as well. The purpose is to analyze the role of corporate branding and to know about influencing factors during purchase of a mobile phone connection.

\section{Objective}

It is seen the most of the companies in mobile phone telecommunication promote more their corporate name than the product/service they offer to the customers. The purpose of this study is to analyze the role of corporate branding in mobile telecommunication industry. What are reasons that make customers purchase mobile phone connection of any particular company. Either it is because of corporate brand or it is because of the service, loyalty, price or any other reason. This research will examine that in mobile phone telecommunication either corporate brand is sufficient for a long term customer base, and that brand association or there are any other factor for long time survival of the company. As product/service brands are not long term brands as compared to corporate brand in mobile phone telecommunication so focus will be to know about corporate brand and its presence in the consumer's mind. Corporate brand has more dominant reflection in mind of mobile phone consumers and which has long lasting association with consumers. This research is carried out to find out the approximate solution of identified problem with the help of literature and Questionnaire.

\section{Methodology}

This is a quantitative study. A questionnaire is used in order to investigate corporate branding and other influencing factors involved in purchase decision of the customers. Population selected for this study is Belgrade University students which is the most of Serbian youth segment who are studying here, and is a valuable source that gives precise information with high probability about market preferences according to the Research of Serbian republic statistical office. Primary data are obtained by collecting data from questionnaire and interview, while the secondary data are collected from various reliable sources. Primary data provide reliable content in accordance with a secondary data obtained by Serbian republic statistical office and with a Research of competitor and consumer preferences insight provided by Telenor Company. The analysis of the data has been performed in accordance with the chosen theories and summarized in a table, which serves as a tool for deriving reliable and relevant conclusions. The sample size was determined by conducting a primary study and defining the variance of primary sample and the intended number of samples was selected carefully and randomly from the population. Then the validity and reliability of the questionnaire was determined. The used questionnaire in this research consisted of 7 common, and 30 specialized questions which were supporting the hypotheses of the research. Data was analyzed using the frequency percent techniques, and in the chapter related to the deductive statistics, one-sample $t$ test was used to analyze and approve/disapprove the questions supporting the research hypotheses.

\section{Data Collection \& Results}

Students of Belgrade University were the target population. Questionnaire started with a basic question that either he/she is a student of Belgrade University or not with age and gender information. The total sample population was students of Belgrade University. Out of 702 students, 372 $(53 \%)$ were female while $330(47 \%)$ were male. Ratio of female and male is almost equal to avoid biasness. According to research topic students were asked that do they have a mobile phone connection and used three main service providers as reference. All 702 students had mobile phone connections. Question; "Which service provider's connection do you have?" The students had three different choices to select a brand. If anyone was not using anyone of the three brands then he/she could mention it in Others category. The result for this is shown in the following figure.

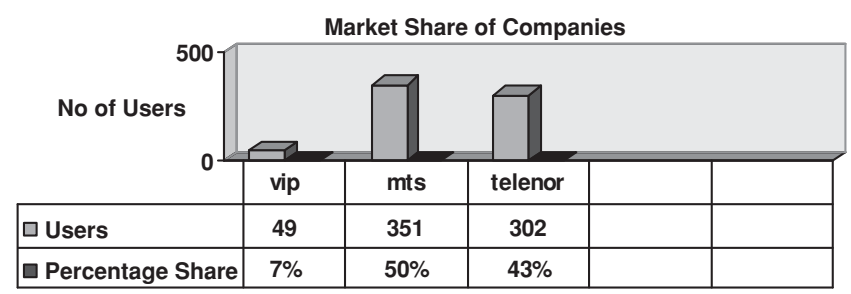

Question: "Why did you choose the above company (Brand)?" To check the response of students as they are customers of service provider, the question had four options to answer. Options are company name (brand), Service \& quality (S\&Q), loyalty \& Trust (L\&T) and finally The Price (P). 9\% selected company name (Brand), 20\% selected S\&Q, $10.4 \%$ selected L \& T, 54\% selected price, $1.4 \%$ selected $\mathrm{L} \& \mathrm{~T}+\mathrm{P}, 4 \%$ selected $\mathrm{S} \& \mathrm{Q}+\mathrm{P}$, and $0.3 \%$ selected $\mathrm{B}+\mathrm{P}$ as a influencing factor for their selection of mobile phone connection. The highest influencing factor for their purchase is price then $S \& Q, L \& T$ and Brand respectively. The results for this questionare shown in the following figure.

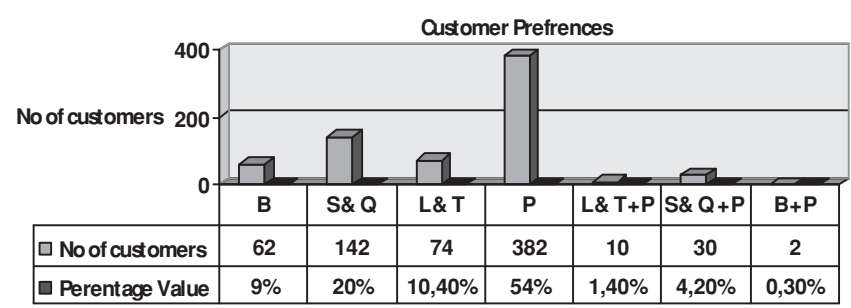




\subsection{Brand}

This section will show different results obtained for corporate brand mentioned as company name (Brand) in the questionnaire. There were 62 respondents who selected brand as influencing factor, which is $9 \%$ of total sample population.

Question: "Do you have any emotional attachment with your chosen brand?" This question is put in the sub questionnaire of the brand. In order to know about those respondents who had brand as influencing factor for their purchase. The data is gathered for their emotional attachment with the brand. Different results were obtained.

$6 \%$ of 62 were highly agree, $16 \%$ were agree, $32 \%$ responded as average and somewhat disagree and $13 \%$ as Disagree that they have emotional attachment with the brand. The results are shown graphically in the figure below.

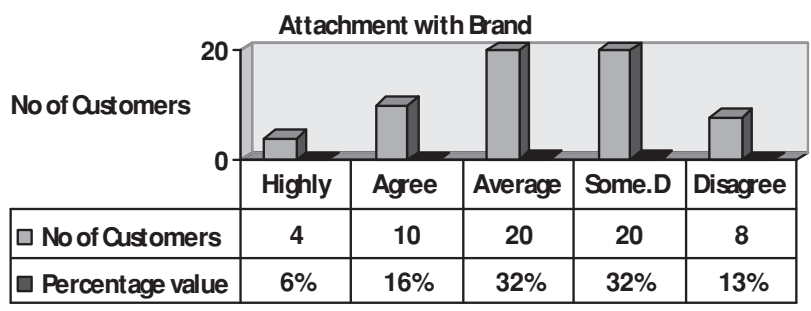

Question: "Are you satisfied with your chosen brand?" This question is also contained in the sub questionnaire of Brand. Purpose of this question was to know about the satisfaction level of the respondents who selected Brand as an influencing factor for their purchase. Different set of responses were obtained for this question with $16 \%$ of 62 as highly satisfied, $42 \%$ as satisfied, $23 \%$ as average and $10 \%$ as somewhat dissatisfied and dissatisfied. The results are shown graphically in the following figure.

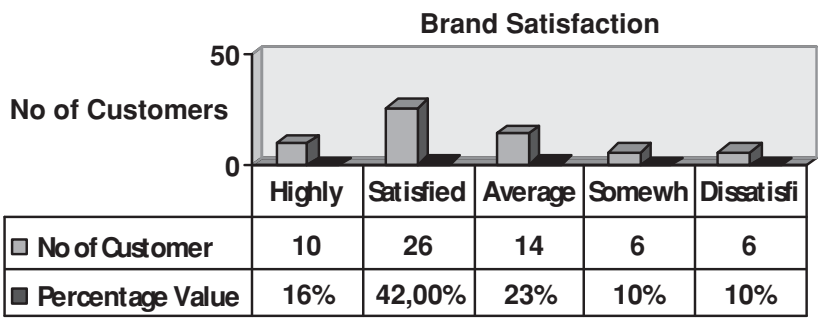

\subsection{Service \& Quality}

In this part results obtained for service \& quality will be explained. There were 142 respondents who selected service $\&$ quality as a major factor for their purchase decision. It is $20 \%$ of the total sample.

To check the importance of services from those respondents who chose services \& quality as their influencing factor for purchase, a question was asked: "Do you chose this connection only due to services offered?" $14 \%$ respondents of 142 replied that services are highly important that they chose this connection only due to services offered while $16 \%$ answer that services are important for their purchase and 34\% answered for average which is highest percentage. $20 \%$ answered for less important while $14 \%$ said that only services are not important for their purchase. The results are shown in following graph.

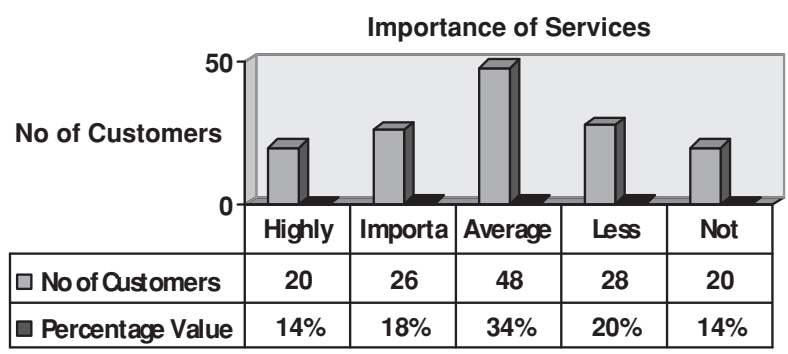

Respondents were also asked about the quality of the brand which they are using in order to investigate the importance of quality associated with that particular brand. They were asked that "How do you see the quality of this brand?" . Different results were obtained from this research, $30 \%$ of 142 respondents, who selected service and quality as an influencing factor, replied as very good while 54\% replied as good. $15 \%$ said that it was average. Only 2 respondents said that it was bad. The results are shown in the graph below.

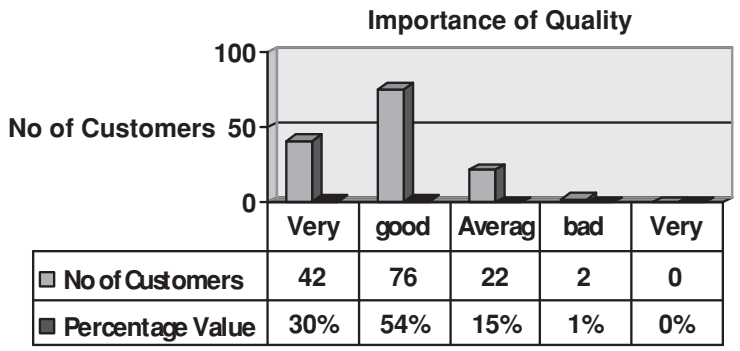

\subsection{Loyalty and Trust:}

As mentioned earlier that the research questionnaire is comprised of four parts. Loyalty and trust is one of them. The questionnaire has different questions to check the loyalty and trust of those respondents who chose their mobile phone connection because they are loyal to the company as well as have trust on it. $10.4 \%$ of the total sample selected loyalty and trust as a reason for their purchase.

To know the loyalty preferences of the customers either they are loyal to company (brand) or services; this question was asked: "Does this loyalty with company (brand) or with services?"

$5 \%$ respondents of 74 said that they chose this brand because they are loyal to this company (brand). $49 \%$ were of the view that they chose this brand because they are

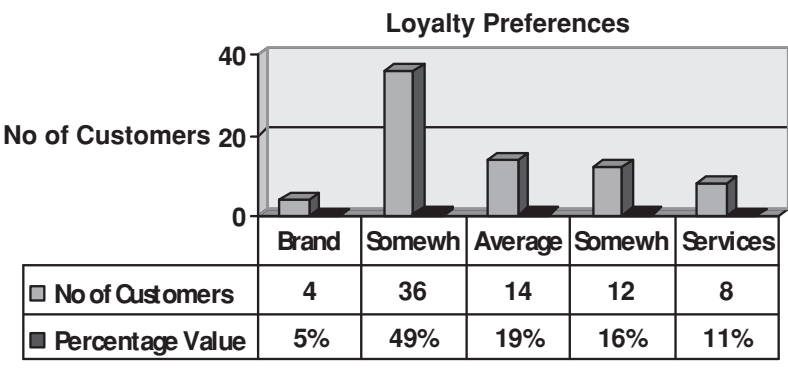


service package that you have?" $8 \%$ respondents answered for brand as a trust factor while $43 \%$ said somewhat brand. $30 \%$ said that their trust in on brand as well as on service package. $8 \%$ and $11 \%$ replied as somewhat service and services respectively. Results are presented graphically below.

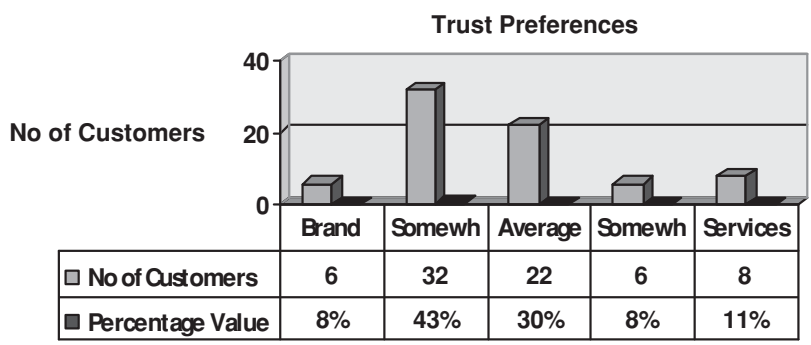

In order to investigate about loyalty and trust of the respondents, a very basic question was asked from the respondents: "For how long you are using this brand?" This question revealed data which show respondents as being loyal to the brand. As it is shown in the following graph that the 16 respondents out of 74 are using their brand for 5 or more years, 6 are using for 4 years, 5 for 3 years and 6 for 2 years. Data is shown graphically in the below figure.

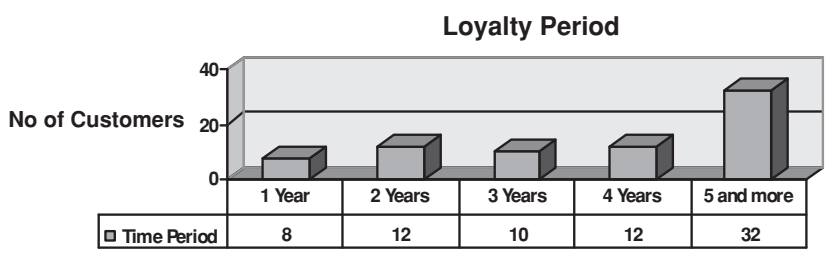

\subsection{Price}

Fourth part of the questionnaire deals with price as a reason for the purchase of the mobile phone connection and also is very important. This part has three different graphical presentations in which relationship of price is discussed with different other factors. This part is $54 \%$ of the total sample population, which makes it biggest in all four main categories.

To examine the relationship between price and company (brand), respondents were asked that: "Do you prefer price or company name (brand)?" In reply to this question different set of results obtained. It shows quite strange result that $58 \%$ respondents said that they prefer price most and only $1 \%$ said that they prefer brand to price. $19 \%$ said that they prefer price as well as brand while making a purchase decision. 28\% were not sure about it but they were more inclined toward price. Following graph shows the results.

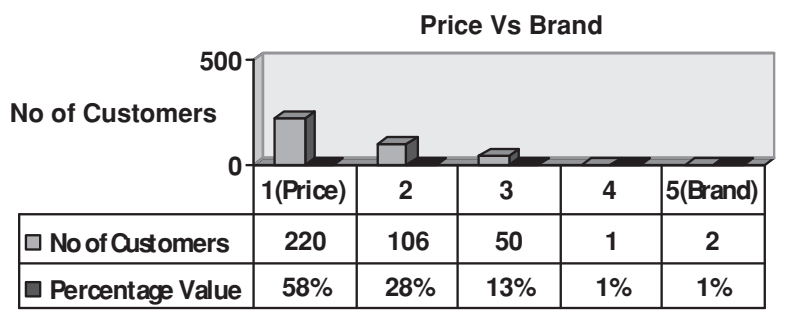

"How high was the impact of price towards your purchase decision?" was the question asked to know about impact of price on purchase, whether it was high or low.

During research it is found that $37 \%$ respondents out of 382 replied that the impact of price was very high on their purchase, $33 \%$ said that it was high. The impact of price was average for $24 \%$ of the respondents. $4 \%$ and $3 \%$ believed that it is low and very low respectively. The graph below shows the result for this question.

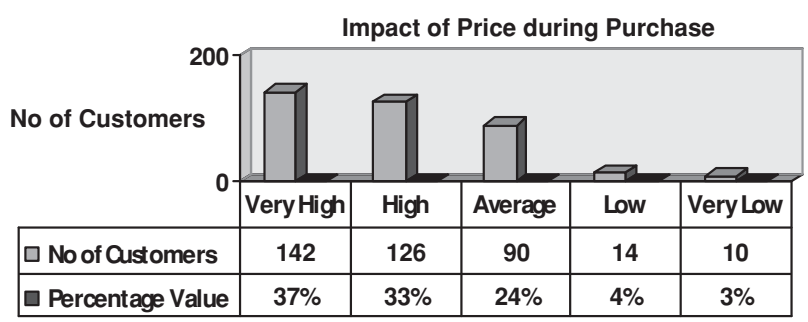

To check the utility of customer which he/she is receiving in the shape of services in accordance with the price, the following question was asked: "Do you think price paid is justifiable to services?" $16 \%$ respondents of 382 were highly agree, $41 \%$ were agree, $30 \%$ average, $12 \%$ were somewhat disagree and $1 \%$ were disagree that services of their chosen brand are good enough with the price of that services. Below the data is presented graphically.

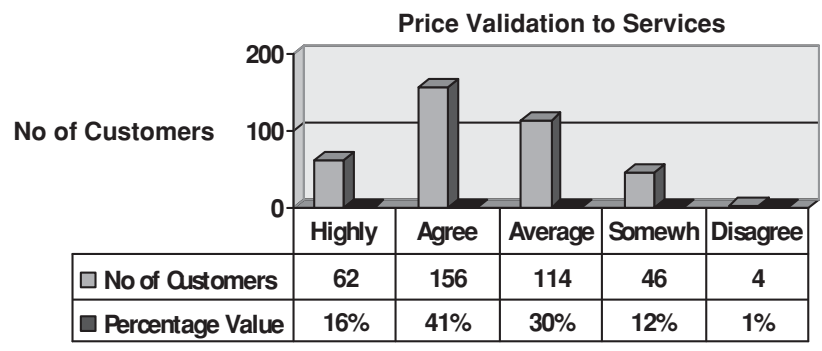

\subsection{Switching}

Switching is discussed in all four main parts of the questionnaire. In order to know about the switching different set of questions were asked. To investigate past and expected switching whether a customer is switched due to brand or service \& quality and will switch due to less price or due to any change in loyalty and trust, for this motive;

Past switching is discussed in relation with brand and also with service \& quality while Expected switching is discussed in relation with price and also with loyalty and trust.

\subsection{Past switching}

To explore how many respondents switched due to brand two questions were added into questionnaire asking them "Was it your first choice or you switched from any other brand?" and "Switched due to brand or any other reason?" 38 out of 62 switched and all switched due to brand.

To investigate switching in service \& quality, respondents were asked that „Did you switch from any other network?” 
48 out of 142 responded as YES while 94 said NO. The data for above two questions is presented graphically in following figure.

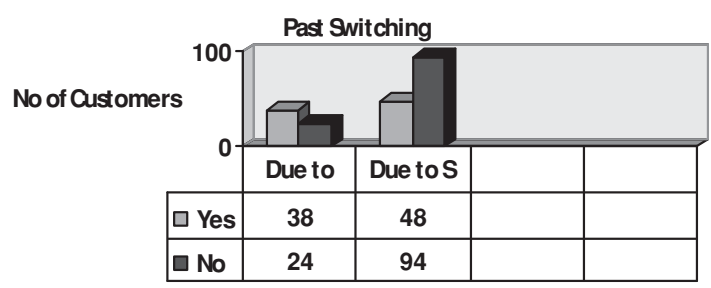

\subsection{Expected Switching}

As expected switching is discussed in price and loyalty \& trust, so in case price respondents were asked that "Will you switch, if low price brand is offered?" $60 \%$ said YES while $40 \%$ said NO.

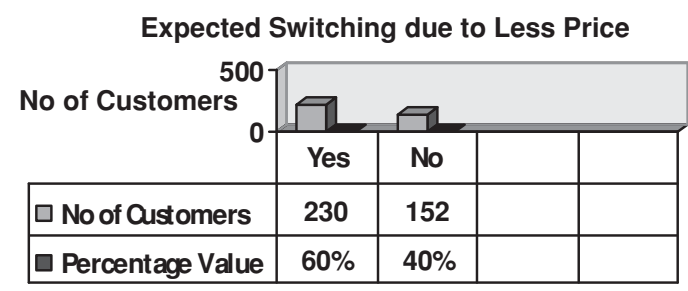

Whereas in case of loyalty and trust respondent were asked "Would you like to run off from existing brand?". Respondents were given four options, (i) promise breakage (ii) less services quality (iii) charge high price as compared to quality and (iv) any other. 12 out of 74 respondents chose promise breakage as point of switching, 30 pointed out less services quality, 28 respondents will run off if high price is charged for low quality and 4 selected any other. Data is presented graphically in the figure below.

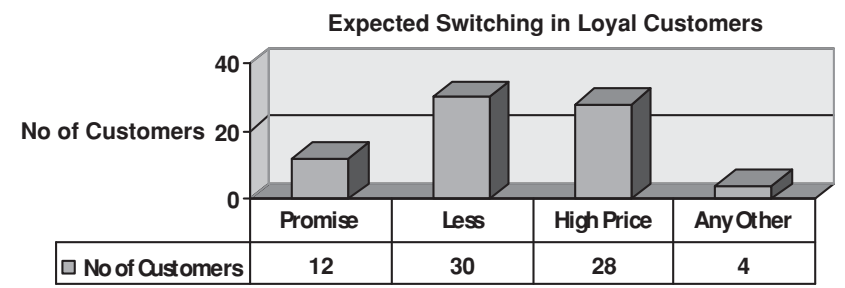

\section{Analysis}

Marketing theories suggest that corporate branding will boost the consumer awareness about the products as well about the corporation (Souiden, et. al., 2006). Strong corporate recognition attracts the customers and employees (Xie \& Boggs, 2006). Corporate recognition can be gained through corporate branding which is helpful for better market share. Empirical data shows that price has a dominant factor for a customer during the purchase of a mobile phone connection. MTS has 50\% share among the sample population and their slogan is "Always the cheapest one" gives the advantage for this high market share. Telenor is at 2nd place with $43 \%$ share. Kotler, (1994) states that price is the one element of marketing mix and is very important. This is shown in this study that the company having low price strategy is dominating the telecommunication market in the perfect competition. As this study indicates customers are more willing to pay less prices and are more inclined towards MTS. MTS has made strong recognition as a low price brand which is communicated to consumers.

\subsection{Affect of Brand Image on Market Share}

Souiden, et. al., ( 2006) states that sales and market share is directly affected by corporate image and building up loyal customers. Empirical data shows that MTS has high market share among sample population and Telenor has slightly lower market share than MTS even it entered in the market in 2006 because Telenor has worldwide recognition. High market share is helpful in building up corporate image, so empirical implies to this theory. Importance of corporate brand in telecommunication is not same like other industries. In mobile phone telecommunication purchase settings are continuous and different than the purchase settings of retails stores ((Ranaweera \& Prabhu, 2003). Empirical data shows that 382 out of 702 argue that they chose the connection because of price factor. While 62, 142, 74 said that they like brand, S\&Q and L\&T respectively. So the preferences of the customers about the connection are different but more centered on price. So it satisfies the above theory of Ranaweera \& Prabhu, (2003) that purchase settings are different in mobile telecommunication industry as compared to other industries. MTS and Telenor have high market share as compared to VIP because they have good brand image which helps them in gaining this share. Telenor is having more market share around the globe as compared to MTS or VIP. But this study shows MTS having slight edge over Telenor due to price other factors remaining constant.

\subsubsection{Attachment with the Brand and Role of Corporate Brand}

Customers have emotional attachment with the brand as stated by Kay (2006), that brands are incorporated into the lives of the customers. But this research presents that $32 \%$ of 30 respondents of this study, who purchased their connection because of brand, argued that they have average attachment with the brand while $32 \%$ are somewhat disagree to the question of emotional attachment with the brand. Role of corporate brand in such situation is a communicator of offers ie low price, wider network, new services etc. the results are in accordance with the theory of Souiden et. al., (2006) that corporate branding will boost the consumer awareness about product and corporation.

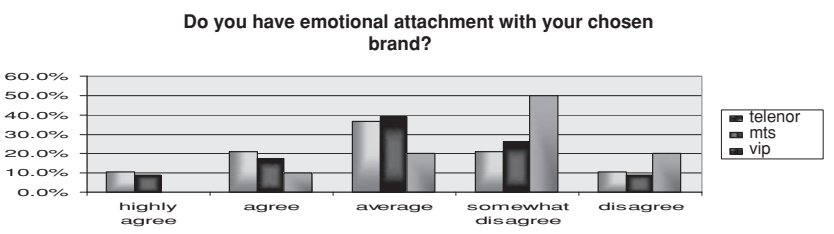


Table 1. Emotional attachment to the brand

\begin{tabular}{|c|c|c|c|c|c|c|c|}
\hline & \multirow[t]{2}{*}{ Brand } & \multicolumn{3}{|c|}{ Descriptive statistics } & \multirow{2}{*}{\begin{tabular}{|c}
$\begin{array}{c}\text { Omnibus } \\
\text { Test }\end{array}$ \\
Kruskal- \\
Wallis \\
ANOVA
\end{tabular}} & \multicolumn{2}{|c|}{$\begin{array}{c}\text { Mann- } \\
\text { Whitney } \\
\text { U-test }\end{array}$} \\
\hline & & $\mathrm{N}$ & Mean & SD & & MTS & VIP \\
\hline \multirow{3}{*}{$\begin{array}{l}\text { Do you have } \\
\text { emotional } \\
\text { attachment } \\
\text { with your } \\
\text { chosen brand? }\end{array}$} & Telenor & 19 & 3.00 & 1.16 & $0.033^{*}$ & 0.772 & $0.028 *$ \\
\hline & MTS & 23 & 2.91 & 1.08 & & - & $0.025 *$ \\
\hline & VIP & 20 & 2.20 & 0.89 & & - & - \\
\hline
\end{tabular}

In terms of emotional attachment (Table 1), the difference between the three brands was statistically significant. Telenor and MTS users reported a significantly higher emotional attachment then VIP users, while difference between Telenor and MTS was not statistically significant.

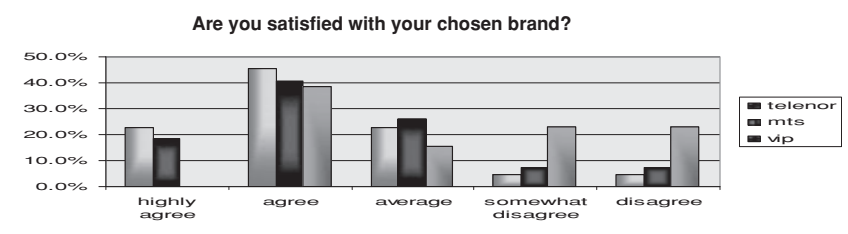

Table 2. Satisfaction with the brand

\begin{tabular}{|l|l|c|c|c|c|c|c|}
\hline & Brand & \multicolumn{3}{|c|}{ Descriptive statistics } & $\begin{array}{c}\text { Omnibus } \\
\text { Test }\end{array}$ & $\begin{array}{c}\text { Mann- } \\
\text { Whitney } \\
\text { U-test }\end{array}$ \\
\hline & N & Mean & SD & $\begin{array}{c}\text { Kruskal- } \\
\text { Wallis } \\
\text { ANOVA }\end{array}$ & MTS & VIP \\
\hline $\begin{array}{l}\text { Are you } \\
\text { satisfied } \\
\text { with iou } \\
\text { chosen brand? }\end{array}$ & Telenor & 22 & 3.77 & 1.02 & $0.042 *$ & 0.497 & $0.020 *$ \\
\cline { 2 - 8 } & MTS & 27 & 3.56 & 1.12 & & - & 0.056 \\
\cline { 2 - 8 } & VIP & 13 & 2.69 & 1.25 & & - & - \\
\hline
\end{tabular}

Telenor users were satisfied with their phone service provider more then VIP users (Table 2). The differences between Telenor and MTS and between MTS and VIP were not significant.

\subsection{Service \& Quality}

\subsubsection{Services and the brand}

Whenever anyone purchases any product or service for the first time, there is always some risk associated with it. And this risk is more common in case of services. Degree of perceived risk is highest when customer can't evaluate services before purchasing them (Ozer et. al., 2005). In order to investigate this phenomenon respondents were asked about this factor and to know the importance of the services to the respondents that "Did you purchase this connection only due to services offered?" 20\% respondents of 142 replied as somewhat disagree while $14 \%$ replied as disagree.
Remaining are indifferent in this regard. This shows that whenever a customer is faced with services he/she is not sure about it that either it will be good or bad because of the feature of services like heterogeneity, intangibility etc given by Ozer et. al., (2005).

Until unless customers do not have any experience with the services they can not evaluate its importance. But it must be remembered that it is only in case of services not in case of products. 8 out of 142 respondents had MTS connection and were highly agreed as well, thus MTS was on top with highly agreed. 16 respondents had Telenor connection and were agree to the question, so Telenor is top in this category while VIP is at second in this category with 6 users. And 34 respondents who responded as average have Telenor connection, while 10 had VIP connection in this category.

Respondents who were somewhat disagree with this connection 10 of them have MTS connection while 10 have VIP connection. 3 having Telenor and VIP each were disagree to this question. This presented a result that Telenor is good at services and customers do know that a particular package has good services or not but overall Telenor. The big reason for this in mobile phone telecommunication is that a company has a single net work for all customers but services may vary in customer services for different groups' e.g. corporate connection but this research only includes the sample population of Belgrade University.

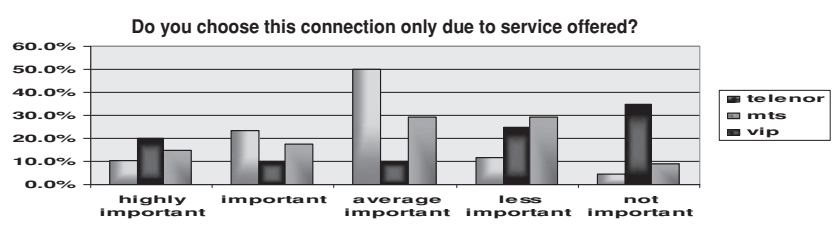

Table 3. Importance of services

\begin{tabular}{|l|c|c|c|c|c|c|c|}
\hline & Brand & \multicolumn{3}{|c|}{ Descriptive statistics } & $\begin{array}{c}\text { Omnibus } \\
\text { Test }\end{array}$ & $\begin{array}{c}\text { Mann- } \\
\text { Whitney } \\
\text { U-test }\end{array}$ \\
\hline & $\mathrm{N}$ & Mean & SD & $\begin{array}{c}\text { Kruskal- } \\
\text { Wallis } \\
\text { ANOVA }\end{array}$ & MTS & VIP \\
\hline $\begin{array}{l}\text { Do you } \\
\text { choose this } \\
\text { connection } \\
\text { only due to } \\
\text { service offered? }\end{array}$ & Telenor & 68 & 3.24 & 0.95 & & $0.005^{*}$ & 0.229 \\
\cline { 2 - 8 } & MIP & 40 & 2.55 & 1.55 & $0.014^{*}$ & - & 0.094 \\
\hline
\end{tabular}

Services were more important to Telenor users in comparison to the MTS users (Table 9). Differences between Telenor and VIP and between MTS and VIP were not statistically significant.

\subsubsection{Quality and the brand}

Quality is over all judgment about excellency and superiority of the service (Ozer et. al., 2005). The research shows that $20 \%$ of total sample population selected S\&Q as a reason for buying a connection which is greater than brand 
and L\&T but less than price. And the difference is not very small between price and S\&Q. the research shows than 67, 63, and 12 respondents out of 142 are using Telenor, Mts, Vip, respectively, which show Telenor being a leader in service \& quality. As Ozer \& Aydin (2005) state that quality of a service is hard to measure but customers need a good service quality with price even it is difficult to measure. Research shows that $4 \%$ of the total sample selected S\&Q with price. Which gives an idea that one factor is very important but if supported by another factor. Those who chose service \& quality as a measuring tool during the purchase process, $54 \%$ of them replied that the quality of the brand is good and they are enjoying it. While 30\% said that it is very good. Respondents for this question also had different mobile phone connection, 20, 18 and 4 had Telenor, Mts and Vip respectively and also said that quality of their chosen brand is very good. While 41, 27 and 8 have Telenor, Mts, Vip respectively and said the quality of their brand is good. 12,8 and 2 said that quality of their brand is average. While only 2 respondent having Telenor responded it as bad quality brand. The result shows that Telenor has high number of customers, who have experience of good quality with Telenor. So they see Telenor as a high quality brand and this is good for the future of Telenor and for a big customer base.

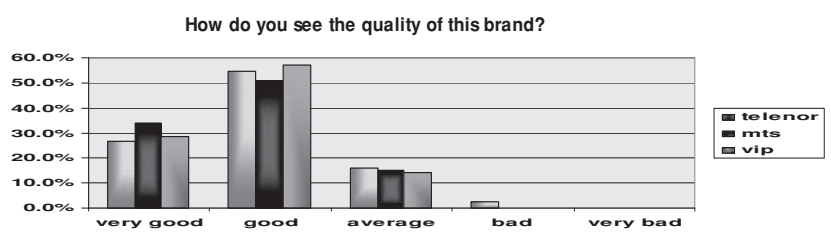

Table 4. Quality of the brand

\begin{tabular}{|l|c|c|c|c|c|}
\hline & Brand & \multicolumn{3}{|c|}{ Descriptive statistics } & $\begin{array}{c}\text { Omnibus } \\
\text { Test }\end{array}$ \\
\hline & & N & Mean & SD & $\begin{array}{c}\text { Kruskal- } \\
\text { Wallis } \\
\text { ANOVA }\end{array}$ \\
\hline $\begin{array}{l}\text { How do you } \\
\text { see the } \\
\text { quality } \\
\text { of this } \\
\text { Brand? }\end{array}$ & Telenor & 75 & 4.05 & 0.73 & \\
\cline { 2 - 6 } & MTS & 53 & 4.419 & 0.68 & 0.631 \\
\cline { 2 - 6 } & VIP & 14 & 4.14 & 0.66 & - \\
\hline
\end{tabular}

Quality of the brand was said to be on the same level by respective users of the three providers (Table 4). The differences were not statistically significant.

\subsection{Loyalty and Trust}

Customer loyalty is very necessary for the firms to be become market leader and for a big customer base with long term relationship (Ozer et. at., 2005, Souiden et. al., 2006, Ranaweera \& Prabhu, 2003). It is a very difficult in GSM technology to make loyal customers when there is a chance for switching. But it is part of service provider that they make strategies to get loyal customers. It is not a mature industry and also dependent on information technology so rapid changes are there. In this situation a big customer base is needed which can be gained through different offers but if company make loyal customers. It is beneficial for a company in long term. This study involves a question regarding loyalty that a respondent is either loyal to brand or services, which he/she is using. From sample population $10.4 \%$ respondents said that they are loyal to the company and they trust on it. Even it is a small proportionate to price and S\&Q but is giving a view about corporate brand loyalty or services loyalty. Services loyalty means if another company offers same services then he/she can easily switch to that company. The result shows that $2 \%$ and $49 \%$ respondents of 62 answered for brand and for somewhat brand respectively, while $6 \%$ and $4 \%$ replied for somewhat services and services. The results shows that majority of the customers are loyal with brand. In this question it is also seen that customers are having different brands. Like four customers having Telenor connection replied that they are loyal to company. While 16, 14, 6 customers having Telenor, Mts and Vip respectively replied as somewhat brand. 4, 6 and 2 customer having Telenor, Mts and Vip connections respectively replied as average importance for the brand and the services. While 2 and 10 customers having Mts and Vip connections respectively replied as somewhat services. While there were only 2, 4 and 2 customer having Telenor, Mts and Vip connections respectively replied that they are fully in favor of services. This result shows a scattered result for the loyalty of the customer. There is no single brand which came up as leading brand in loyalty preferences.

\section{Does this loyalty with company (brand) or with services?}

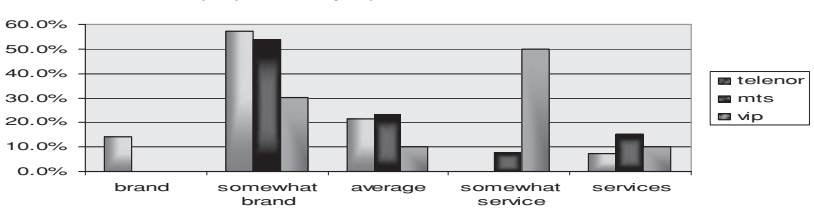

Table 5. Loyalty to the brand vs. loyalty to the services

\begin{tabular}{|l|c|c|c|c|c|c|c|}
\hline & Brand & \multicolumn{3}{|c|}{ Descriptive statistics } & $\begin{array}{c}\text { Omnibus } \\
\text { Test }\end{array}$ & \multicolumn{2}{|c|}{$\begin{array}{c}\text { Mann- } \\
\text { Whitney } \\
\text { U-test }\end{array}$} \\
\hline & N & Mean & SD & $\begin{array}{c}\text { Kruskal- } \\
\text { Wallis } \\
\text { ANOVA }\end{array}$ & MTS & VIP \\
\hline $\begin{array}{l}\text { Do this loyalty } \\
\text { with company } \\
\text { (brand) or } \\
\text { with } \\
\text { services }\end{array}$ & Telenor & 28 & 3.71 & 0.98 & & 0.051 & $0.001 *$ \\
\cline { 2 - 8 } & MTS & 26 & 3.15 & 1.12 & $0.002 *$ & - & 0.083 \\
\cline { 2 - 8 } & VIP & 20 & 2.6 & 1.05 & & - & - \\
\hline
\end{tabular}

When asked where their loyalty lies, Telenor users declared a higher degree of loyalty to brand vs. loyalty to services, when compared with the VIP users (Table 5). The other two comparisons were not statistically significant.

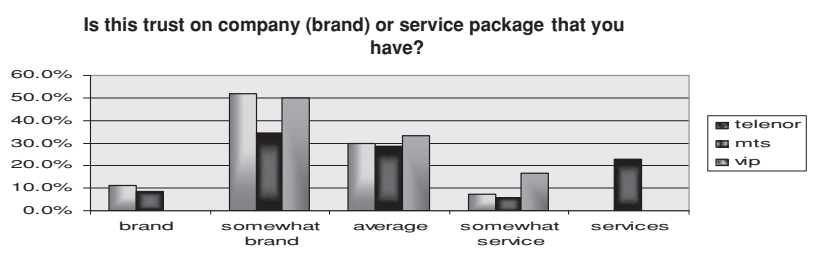


Table 6. Trust on the company vs. trust on services

\begin{tabular}{|l|c|c|c|c|c|}
\hline & Brand & \multicolumn{3}{|c|}{ Descriptive statistics } & $\begin{array}{c}\text { Omnibus } \\
\text { Test }\end{array}$ \\
\hline & & $\mathrm{N}$ & Mean & SD & $\begin{array}{c}\text { Kruskal- } \\
\text { Wallis } \\
\text { ANOVA }\end{array}$ \\
\hline $\begin{array}{l}\text { Is this trust on } \\
\text { company } \\
\text { (brand) or } \\
\text { service package } \\
\text { that you have? }\end{array}$ & Telenor & 27 & 3.67 & 0.78 & \\
\cline { 2 - 6 } & VIP & 35 & 3.00 & 1.31 & 0.130 \\
\hline
\end{tabular}

The degree of trust on company was not statistically significant between the three providers (Table 6).

When customer has trust in a brand it means customer has positive buying behavior towards the brand (Ozer \& Aydin, 2005). Trust is strong predictor of customer retention and customer must realize that they will continue getting benefits in the future as well (Ranaweera \& Prabhu, 2003; Ozer \& Aydin, 2005). In this research respondents, who selected L\&T as an influencing factor for their purchase, were asked that either they trust their selected brand or they trust on the services. $8 \%$ replied as brand being a trust worthy element in their mutual relationship while $43 \%$ replied that somewhat brand is important for long term relationship between company and them. While only $8 \%$ and $11 \%$ thought that somewhat services and services are important respectively. This is in accordance with the theory that trust is key factor for long term relationship and it must be between company and the customer. It is also seen from this question that 3 and 3 customers having Mts and Telenor brands replied that they trust their brand. While 16, 10 and 6 customers having Telenor, Mts and Vip connections respectively were in favor of somewhat brand. 8, 10 and 4 customers having Telenor, Mts and Vip connections respectively were average respondents. 2, 2 and 2 customer having Telenor, Mts, Vip respectively replied as somewhat services. While there were only 8 customers who are using Mts brand were in favor of services as a trust worthy element. This also indicates a scattered result for the trust preferences of the customers. There is no single brand which can be considered as a leading brand among customer choices.

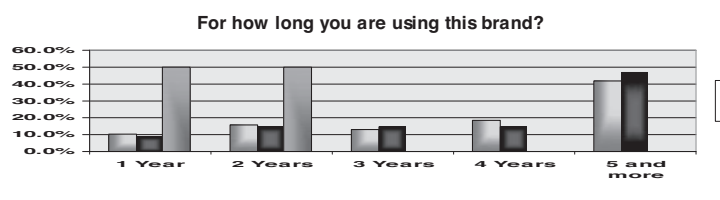

Table 7. Loyalty period

\begin{tabular}{|l|c|c|c|c|}
\hline & Brand & \multicolumn{2}{|c|}{ Descriptive statistics } & $\begin{array}{c}\text { Omnibus } \\
\text { Test }\end{array}$ \\
\hline & & $\mathrm{N}$ & Mean (years) & $\begin{array}{c}\text { Kruskal- } \\
\text { Wallis } \\
\text { ANOVA }\end{array}$ \\
\hline $\begin{array}{l}\text { For how long } \\
\text { you are } \\
\text { using } \\
\text { this brand? }\end{array}$ & Telenor & 38 & 4 & \\
\cline { 2 - 5 } & MTS & 34 & 4 & 0.138 \\
\cline { 2 - 5 } & VIP & 2 & 1.5 & \\
\hline
\end{tabular}

There was no statistical significance between the three brands in terms of the duration of the loyalty period, though lack of power is obvious due to the small sample of VIP users (Table 7).

\subsection{Price}

There are many factors available for pricing of any product/service. The price is set according to many factors like stage of product life cycle, competitor's price, segmentation, positioning of product or service or any differential advantage. So price is very important in marketing mix.

Price has very important role in any purchase decision. It is important for company's point of view during the process of planning as well as for the customer when making purchase of any particular product. Companies use different set of pricing strategies, as given by Daly, (2002), in order to attract customers. Like MTS is presented and perceived as a company with low calling rates.

\subsubsection{Impact of price}

Customers are also very price sensitive in Telecommunication sector (Ozer \& Aydin, 2004). Price is very sensitive and dynamic issue. As in this research respondents were asked that "How was the impact of price on their purchase decision?".

In answer to this question $37 \%$ of 382 respondents, who chose price as an influencing factor, replied as very high while $33 \%$ replied as high. There were $24 \%$ customers who said that impact of price on their purchase decision was average and $4 \%$ \& $3 \%$ replying as low and very low respectively. This discussion yields result that price has very high impact on the purchase decision of the price sensitive customers, as stated in theory. Role of the pricing can't be neglected even in other cases where customers are not price sensitive but it dominates where customers are price sensitive.

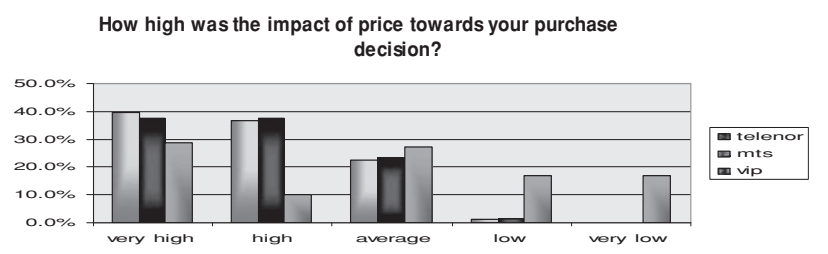

Table 8. Impact of price on the purchase decision

\begin{tabular}{|l|c|c|c|c|c|c|c|}
\hline & Brand & \multicolumn{3}{|c|}{ Descriptive statistics } & $\begin{array}{c}\text { Omnibus } \\
\text { Test }\end{array}$ & \multicolumn{2}{|c|}{$\begin{array}{c}\text { Mann- } \\
\text { Whitney } \\
\text { U-test }\end{array}$} \\
\hline & & N & Mean & SD & $\begin{array}{c}\text { Kruskal- } \\
\text { Wallis } \\
\text { ANOVA }\end{array}$ & MTS & VIP \\
\hline $\begin{array}{l}\text { How high was } \\
\text { the impact of } \\
\text { price towards } \\
\text { your purchase } \\
\text { decision? }\end{array}$ & Telenor & 174 & 4.1 & 0.81 & & 0.694 & $0.001 *$ \\
\cline { 2 - 8 } & VIP & 149 & 4.11 & 0.81 & $0.001 *$ & - & $0.001 *$ \\
\hline
\end{tabular}


The impact of price on purchase was statistically significantly different between the three brands (Table 8). The price was of greater impact on the purchase decision for MTS and Telenor users when compared to VIP users. There was no significant difference between Telenor and MTS.

\subsubsection{Price Vs brand}

Price affects all service providers but it affects more when there is a perfect competition (Shi et. al., 2006). This study includes the Serbian mobile phone industry and competition is very high in this industry. Companies are well established in the market and targeting customers with low price packages having same services. 382 respondents of total sample population chose the price as a major factor for buying a connection. To find out the view of the customers about price and brand a question was asked: "Do you prefer price or brand?" $58 \%$ respondents said that they like price, $28 \%$ replied as somewhat price, $13 \%$ said that they prefer price as well as the brand. Remaining replied in favor of brand which makes only $2 \%$. Shi et. al, (2006) states that consumer has its own preferences for services. These results satisfy the Shi et. al., (2006) theory that price affects all service providers so this case as well. Research shows that customer preference is not the brand but the price and according to theory customer has own preferences for choice of services. Munnukka, (2005) argues that customers are price sensitive in mobile phone industry, so it is proved by this research.

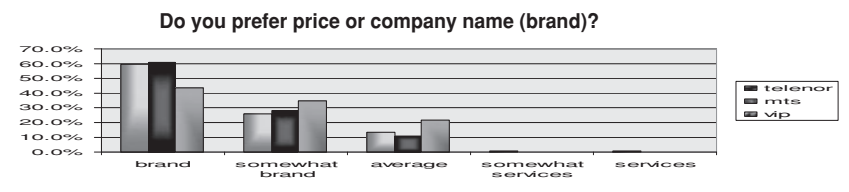

Table 9. Price vs. brand

\begin{tabular}{|l|c|c|c|c|c|}
\hline & Brand & \multicolumn{3}{|c|}{ Descriptive statistics } & $\begin{array}{c}\text { Omnibus } \\
\text { Test }\end{array}$ \\
\hline & & N & Mean & SD & $\begin{array}{c}\text { Kruskal- } \\
\text { Wallis } \\
\text { ANOVA }\end{array}$ \\
\hline $\begin{array}{l}\text { Do you prefer } \\
\text { price } \\
\text { or company } \\
\text { name } \\
\text { (brand)? }\end{array}$ & Telenor & 151 & 4.43 & 0.8 & \\
\cline { 2 - 6 } & MTS & 181 & 4.5 & 0.69 & 0.070 \\
\cline { 2 - 6 } & VIP & 46 & 4.22 & 0.79 & \\
\hline
\end{tabular}

There was no significant difference in preferences toward price or brand between the users of the three providers (Table 9).

\subsubsection{Price for services}

Customer buying behavior has a direct relationship between price and service quality of the product/service, so tradeoff between these two makes increase or decrease in sensitivity towards other factors involved in long term relationship (Munnukka, 2005). Price and service quality are directly proportional, if service quality is high then customers are willing to pay high for it and vice verse. Daly, (2002) has stated different strategies for pricing and value pricing is one of them which could apply in a situation when services have unique value or have a good quality. In this research respondents were asked that "Do you think price paid is justifiable for services offered?”.

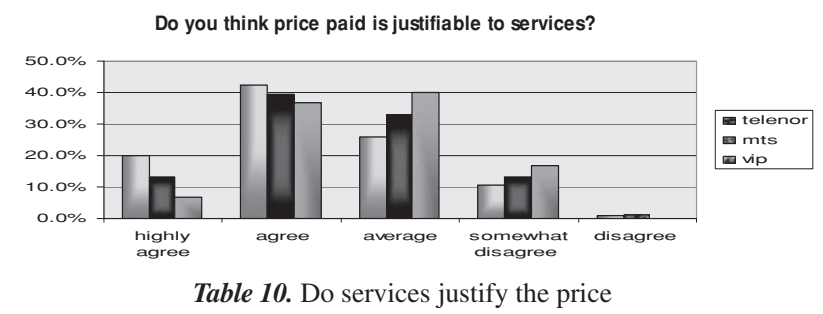

\begin{tabular}{|l|c|c|c|c|c|c|c|}
\hline & Brand & \multicolumn{3}{|c|}{ Descriptive statistics } & $\begin{array}{c}\text { Omnibus } \\
\text { Test }\end{array}$ & $\begin{array}{c}\text { Mann- } \\
\text { Whitney } \\
\text { U-test }\end{array}$ \\
\hline & & N & Mean & SD & $\begin{array}{c}\text { Kruskal- } \\
\text { Wallis } \\
\text { ANOVA }\end{array}$ & MTS & VIP \\
\hline $\begin{array}{l}\text { Do you think } \\
\text { price paid is } \\
\text { justifiable } \\
\text { to services? }\end{array}$ & Telenor & 200 & 3.7 & 0.94 & & $0.039 *$ & $0.030^{*}$ \\
\cline { 2 - 8 } & MTS & 152 & 3.5 & 0.93 & $0.027 *$ & - & 0.317 \\
\cline { 2 - 8 } & VIP & 30 & 3.33 & 0.84 & & - & - \\
\hline
\end{tabular}

Telenor users declared that services of that provider justified the price they paid in a significantly higher degree, than did MTS and VIP users for their respective companies. The difference between MTS and VIP was not statistically significant (Table 10).

As customers are price sensitive in this industry and corporate brand is a main ambassador of its services and price. Customers are used to get idea about services of a company from price. This research shows that $54 \%$ of total sample chose price as a dominating factor for purchase. They chose it because they are satisfied from services.

Answer for above question shows that $16 \%$ and $41 \%$ of 382 said that they are highly agreed and agreed respectively while $30 \%$ selected average. These results show that price paid for services is good enough and justified. Also these results are same to the theory of Munnukka, (2005).

\subsection{Switching}

Switching in telecom is moving from one operator to another due change in service quality, loyalty \& trust, price or brand. As stated in literature, by Ozer et. al. (2005), switching is present not only in monetary shape but it can also be in physical, psychological shapes as well. In this research switching discussed in two ways; past switching and expected switching. Past switching is covering any kind of switching due to brand or service \& quality. While expected switching is covering any kind of switching due to less price offered or change in loyalty to customer. 


\subsubsection{Switching in past}

Switching is easy to measure in telecommunication industry as compared to other industries because in telecommunication switching is more than walking to another store (Ranaweera \& Prabhu, 2003). The reason for the ease of measurement could be that customers can be asked simple question to know about their switching. This was done in this research as well, where respondents were asked very simple questions in shape of yes or no. And from results it was very easy to know about their switching. For switching in past due to company name (brand) shows that 19 out of 31 replied as yes, that they switched because of brand, while 12 replied as no. whereas in service \& quality, results show that 48 out of 142 switched because of service \& quality whereas remaining 94 did not switch. Results show that switching is not hard to measure in mobile telecommunication industry, but it is difficult to switch in this industry.

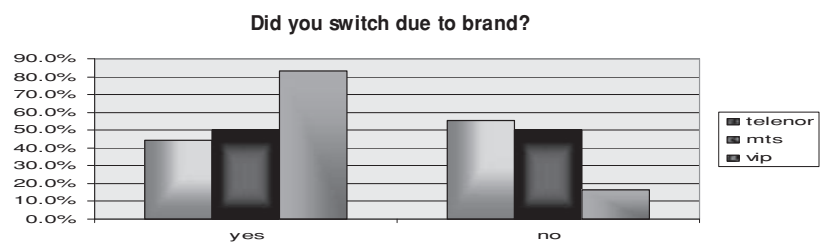

Table 11. Past Switching due to brand

\begin{tabular}{|c|c|c|c|c|c|c|c|}
\hline & \multirow{3}{*}{ Brand } & \multirow{2}{*}{\multicolumn{3}{|c|}{$\begin{array}{c}\text { Descriptive statistics } \\
\mathrm{n}(\%)\end{array}$}} & \multirow{3}{*}{$\begin{array}{c}\text { Omnibus } \\
\text { test }\end{array}$} & \multirow{2}{*}{\multicolumn{2}{|c|}{$\begin{array}{l}\text { Pairwise } \\
X^{2} \text {-tests }\end{array}$}} \\
\hline & & & & & & & \\
\hline & & $\mathrm{N}$ & Yes & No & & MTS & VIP \\
\hline \multirow{3}{*}{$\begin{array}{l}\text { Did you } \\
\text { switch due } \\
\text { to brand? }\end{array}$} & Telenor & 168 & $8(44.4)$ & $10(55.6)$ & $0.017 *$ & 0.732 & $0.008^{*}$ \\
\hline & MTS & 165 & $10(50.0)$ & $10(50.0)$ & & - & $0.018 *$ \\
\hline & VIP & 49 & $20(83.3)$ & $4(16.7)$ & & - & - \\
\hline
\end{tabular}

The percent of VIP users who switched due to brand was higher than those of Telenor and MTS users (Table 11). Difference between Telenor and MTS users was not statistically significant.

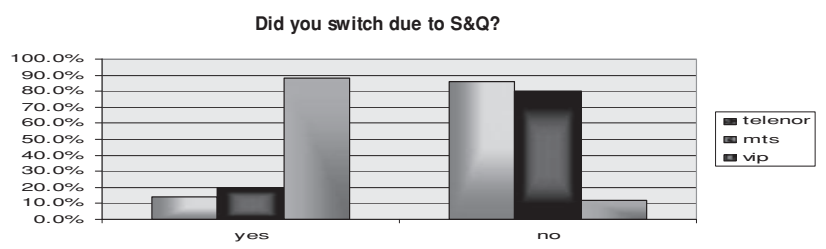

Table 12. Past Switching due to services and quality

\begin{tabular}{|c|c|c|c|c|c|c|c|}
\hline & \multirow{2}{*}{ Brand } & \multicolumn{3}{|c|}{$\begin{array}{c}\text { Descriptive statistics } \\
\mathrm{n}(\%)\end{array}$} & \multirow{2}{*}{$\begin{array}{c}\text { Omnibus } \\
\text { test }\end{array}$} & \multicolumn{2}{|c|}{$\begin{array}{l}\text { Pairwise } \\
\mathrm{X}^{2} \text {-tests }\end{array}$} \\
\hline & & $\mathrm{N}$ & Yes & No & & MTS & VIP \\
\hline \multirow{3}{*}{$\begin{array}{l}\text { Did you } \\
\text { switch due } \\
\text { to S\&Q? }\end{array}$} & Telenor & 168 & $8(13.8)$ & $50(86.2)$ & & 0.388 & $<0.001 *$ \\
\hline & MTS & 165 & $10(20.0)$ & $40(80.0)$ & $<0.001 *$ & - & $<0.001 *$ \\
\hline & VIP & 49 & $30(88.2)$ & 4 (11.) & & - & - \\
\hline
\end{tabular}

The percent of VIP users who switched due to services and quality was higher than those of Telenor and MTS users (Table 12). Difference between Telenor and MTS users was not statistically significant.

\subsubsection{Switching in future}

Loyal customers and price sensitive customers were asked about that either they will switch in the future or not. Ozer et. al., (2005) argues that the loyalty of a customer is being affected by switching and also the trust and satisfaction. This research shows that loyal customers may also be affected and can think about switching because of different reasons, like low quality services are provided, high price is charge, promise breakage etc. The results show that 12, 30, 28 and 4 respondents' loyalty will be affected for promise breakage, low quality service, high price as compared to quality and any other.

Another aspect regarding expected switching is less price offered to price sensitive customers in future. Respondents were asked that "will you switch if low price is offered in the future?" The results indicate that $60 \%$ of 382 replied as yes while $40 \%$ replied as no.

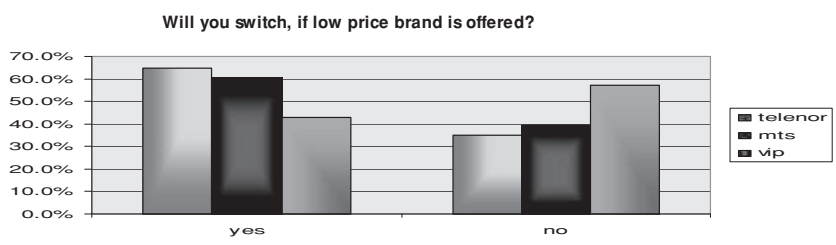

Table 13. Expected switching due to price

\begin{tabular}{|c|c|c|c|c|c|c|c|}
\hline & \multirow[t]{2}{*}{ Brand } & \multicolumn{3}{|c|}{$\begin{array}{c}\text { Descriptive statistics } \\
\mathrm{n}(\%)\end{array}$} & \multirow{2}{*}{$\begin{array}{c}\begin{array}{c}\text { Omnibus } \\
\text { test }\end{array} \\
\mathrm{X}^{2} \text {-test }\end{array}$} & \multicolumn{2}{|c|}{$\begin{array}{l}\text { Pairwise } \\
\mathrm{X}^{2} \text {-tests }\end{array}$} \\
\hline & & $\mathrm{N}$ & Yes & No & & MTS & VIP \\
\hline \multirow{3}{*}{$\begin{array}{l}\text { Will you } \\
\text { switch, if low } \\
\text { price brand is } \\
\text { offered? }\end{array}$} & Telenor & 168 & $109(64.9)$ & $59(35.1)$ & & 0.420 & $0.006 *$ \\
\hline & MTS & 165 & $100(60.6)$ & $65(39.4)$ & $0.021 *$ & - & $0.028 *$ \\
\hline & VIP & 49 & $21(42.9)$ & $28(57.1)$ & & - & - \\
\hline
\end{tabular}

The percent of VIP users who would switch due to price was lower than those of Telenor and MTS users (Table 13). Difference between Telenor and MTS users was not statistically significant.

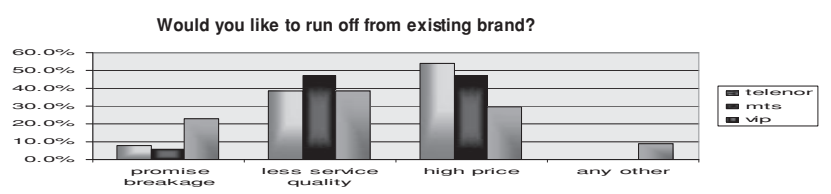

Table 14. Reasons for switching

\begin{tabular}{|l|l|c|c|c|c|c|c|}
\hline \multirow{2}{*}{} & \multirow{2}{*}{ Brand } & \multicolumn{5}{|c|}{$\begin{array}{c}\text { Descriptive statistics } \\
\text { n (\%) }\end{array}$} & $\begin{array}{c}\text { Omnibus } \\
\text { tests }\end{array}$ \\
\cline { 3 - 8 } & & $\mathrm{N}$ & $\begin{array}{c}\text { Promise } \\
\text { breakege }\end{array}$ & $\begin{array}{c}\text { less } \\
\text { service } \\
\text { quality }\end{array}$ & $\begin{array}{c}\text { High } \\
\text { price }\end{array}$ & $\begin{array}{c}\text { Any } \\
\text { other }\end{array}$ & $\begin{array}{c}\text { Fisher's } \\
\text { exact } \\
\text { test }\end{array}$ \\
\hline $\begin{array}{l}\text { Will you } \\
\text { switch, if low } \\
\text { price brand is } \\
\text { offered? }\end{array}$ & Telenor & 13 & $1(7.7)$ & $5(38.5)$ & $7(53.8)$ & $0(0.0)$ & \\
\cline { 2 - 8 } & MIP & 17 & $1(5.8)$ & $8(47.1)$ & $8(47.1)$ & $0 .(0.0)$ & 0.631 \\
\hline
\end{tabular}

High price and lower service quality were two major reasons for possible switching. Furthermore, promise breakage was named by $22.7 \%$ of VIP users. Differences were not statistically significant (Table 14). 


\section{Conclusion}

This research was conducted to know the role of corporate branding in telecommunication industry from different perspectives. This study enables to understand the different views of corporate brand in this industry and also focuses on corporate brand that how it works to capture more and more customers for a big customer base. It is the output of marketing mix that how brand managers' position their brands in the selected industry. The research showed that during positioning of a corporate brand in mobile phone telecommunication industry managers must consider what is the benchmark in the target market to build up a good market share with long term relationship. This research was conducted with one particular group of students with limited income level and they knew about their brand and reason that why did they choose it. This group sees its corporate brand as good services with low price. It is the game of right positioning at right time for a corporate brand to make more as well as loyal customers. The research indicated that customers can switch if they feel that good quality services are being offered from any other service provider with cheap rates. So it is the role of corporate brand to make minds of the customers about it especially in this industry to add new customers. Telenor introduced Olimpic Games and popular singer Vlado Georgiev in Serbia to target a particular segment, which is price sensitive but Telenor is using its name along with it in order to show that they are powered by Telenor, because customers consider it as a good quality service provider with best services. Along with it, Telenor pushes infront the competitors by giving interaction, satisfaction and fun of Telenor's one-stop comprehensive offer in new store's, especially in Telenor's new flagship store, opened in Knez Mihailova Street in Belgrade. In its store which pushes boundaries of customer experience forward in regard to layout, design and service concept, Telenor provides its subscribers with high technology enabling them to choose a service and a phone at their preference in an easier and more entertaining manner. The store boasts with materials and lighting equipment not seen in our country before. The outlet is designed as a place where Telenor subscribers meet and chat. The idea was to use interactive communication in educating and entertaining subscribers while testing everything they are interested in. With this flagship store in Knez Mihailova Street along with other 40 stores across Serbia based on the interactive shopping concept, Telenor has been another step closer to subscribers, since it represents an ultimate result of this concept development and progress.

It was found that majority of the customers in this industry are price sensitive; as this industry is not mature yet and new companies are getting into it, so every firms is focusing hard in broadening its customer base. It was found that corporate branding had nothing to do with the purchase decision of the customers but it is main source that communicates with customers about marketing mix of a company. Corporate brand promotes different factors and these different factors were considered important for customer's purchase. As a whole, services offered are almost same for every company; companies just differentiate them by corporate brands. Service \& quality is another big issue in this industry along with price. This study showed that S\&Q and price are very much interrelated but promoted through corporate brand.

As Telenor is a big corporate brand as compared to other companies involved in this research but Mts has little edge over Telenor because Mts represents itself as cheapest along with best coverage where found. Corporate branding is providing information to the customers about services but it is not an influencing factor for the customers. Customers were asked about their expected switching from existing brand and even loyal customers replied that they will switch in future if they think that company is charging high price as compare to quality. Also price sensitive customers said that they will switch if any competitor brand offers them low price. It means corporate branding cannot influence the customer but works as a medium of communication between company and customer. Customers can only have information from different sources e.g. from print media or broadcast media, about any particular corporate brand. But customers do not go for purchase until or unless certain specific purchase influencing factors like price, service and quality etc are not highlighted with the corporate brand as well.

\section{Recommendation}

This study can be helpful for brand managers in a way that instead of putting more efforts on corporate branding, they must also put more effort in investigating factors which influence customer buying behavior. After a specific period of time it is also very important to reposition a corporate brand; if companies do not do then these companies may face switching from existing customers. It is the era of globalization not only in manufacturing of products but also in service industry. Brands are also getting globalize. Fundamental are same in every market but some factors vary according to market situation. If a brand gets recognition in the international market then it is easy to go into new markets. One big issue in this research is that segment involved into this research belongs to young generation and everybody is a student. It will be interesting to investigate this idea with two or more segments and involving people belonging to all age groups. This will be interesting because the segment involved in this research belongs to only one age group, so one can expect similar results. But when there will be people from all age segments and also from different fields of life then one can check and compare the results of this research with that one. And can better analyze the role of corporate branding in telecommunication. This research will also be helpful for managers to know about the point of view of consumers about corporate brand. This will also help managers for better positioning of their brand to get target recognition for a better and longer relationship. Finally this 
research will be supportive in marketing mix concepts, that how a firm can introduce service, price associated with the particular service and promotional activities to position the correct image of corporate brand as required by managers.

\section{Recommendation for success: How CLM can Optimize Revenue in Today's Telecoms Market?}

Customer Lifecycle Management is a new approach to business that is taking the telecoms world by storm. Its focus on delivering true one-to-one dialogues through targeted marketing campaigns has been instrumental in helping some operators drive up ARPU by $20 \%$ and reduce churn rates by between 40-60\%. Is this the future of marketing?

It focuses on the success of Danish CLM provider Agillic and how the company's technology has helped to improve the fortunes of GSM operator Telenor SONOFON. In today's telecoms world it takes a lot more to keep a customer happy. With so much competition and services available, there is very little reason for any user to stand by an operator that isn't delivering the best services with the best prices in town. Attracting customers and ensuring their loyalty is the main business objective for any operator wanting to compete in today's advanced markets.

But what if everyone seems to be offering the same services? Which operator will the customer choose as a life network provider, and most crucially, how will telecoms providers manage to control the cost of acquiring and retaining these loyal customers in the long run?

The answer to these problems lies in the way in which operators are communicating with each of their customers. With so many telecoms providers to choose from, customers have become immune to traditional and impersonal methods of marketing. Direct campaigns such as telemarketing and direct mails have been used in the past by most operators but they are now becoming too costly to run and are largely ineffective. They also give few options for differentiated marketing. In today's competitive mobile world, a more individualized communication approach is needed to help create a one-to-one dialogue with each high value customer and to help win greater loyalty and trust for an operator's brand. More Customer Interaction research, confirms that any operator that tries to simply push offers onto customers rather than developing an individualized customer interaction is doomed to fail. Inbound interactions- like an online transaction or a customer a customer service call- are initiated by a customer with a specific need. Firms must first ensure that the customer need is addressed by positioning offers or other marketing-driven content in the context of the interaction, The report also stresses that Inbound channels of communications must not be used to simply shove more products towards the customers, as this merely creates negative customer experiences and lowers their satisfaction with their mobile operator. It also leads to greater attributions and ultimately degrades the company's brand.

"To avoid these potential pitfalls, firms should evaluate interaction management software which applies business rules and real-time analytics to a customer profile made up of historical and contextual data. This lack of customer loyalty was the result of Companies inability to communicate more effectively with each of their subscribers and to do so with cross channel synergy. We needed to address this serious challenge before we could implicate possible improvement of their performance in the market. There is therefore a need for companies to find an alternative to adding customer value to their business. One way of achieving this result is by establishing a better relationship with the end user, a bond that can offer a real interaction with individual customers in a relevant and timely way. CLM can make this happen. Providers can learn from Agillic's exceptional technology and customer support. Agillic's CLM solution provided the foundation for launching a communications strategy that could manage both inbound and outbound communications with each customer. It was designed to support successful customer interactions by delivering one to one communication- a capability that Serbian Telecom companies were desperate to gain with their core customers. The solution also gave us the potential to build a relationship with each customer over time by learning from every dialogue. It could also support real-time interaction, allowing us to react swiftly to customer behaviors. So if a user clicked on a web link we could automatically send out a message that was pertinent for that moment in time.

All of these capabilities can help the company to create a targeted marketing campaign that fit the user profile of each individual high value customer. This defines individual approach as Customer Life Cycle Management (CLM). Customer Life Cycle Management (CLM) is next generation CRM. In the past, operators would just target customers with different messages to sell services. CLM is different. You are looking at things from a lifecycle perspective and you are focusing on the individual customer. The big difference between CRM and CLM is that with CRM you are communicating to segments of users when you believe they need something. CLM is more about one to one communication- it's about knowing what they want and delivering it when they want it. Questionnaires and forms are not always reliable when comes to assessing customer preferences. CLM is a big step up from the traditional process of asking customers to fill out a profile sheet. With CLM, an operator can take every interaction that has taken place with each customer and apply special promotions and deals. This communication is triggered automatically when a customer repeats a pattern known to the system. So let's say a user sends many texts in one day- the system can automatically generate a message back to that customer informing them that they can get a special deal on SMS. Another big benefit of CLM is its ability to minimize customer acquisition and retention costs by using low-cost digital channels. This approach also offers low cost of ownership for the operator with a hosted solution that does not require network integration. The result is an easy to use system that provides a flexible, on-demand marketing tool that allows operators to gain full control over their programs. 
Through the use of real-time behavioral based marketing, CLM is a new innovation that is designed to enable operators to manage, evaluate and automate customer interactions to support one-to-one dialogues, based on user profiles and previous exchanges. The focus of CLM is to create a bond between the operator and the customer throughout the customer's lifecycle so that the operator knows exactly what the customer wants and providing that service to them in real-time. This approach has consistently proven to lower churn and increase ARPU for customers.

\section{References: Literature}

Amaratunga D. \& Baldry D. (2001), "Case Study Methodology as a means of theory building" MCB University Press. ISSN 00438022 vol. 50 no. 3 PP. $95-104$

Anisimova A. T., (2007), “The effects of corporate brand attributes on attitudinal and behavioral consumer loyalty" Journal of consumer marketing, Vol. 24 No.7 PP. 395-405

Aperia T., Bronn S. P., Mchultz M. (2004), " Reputation Analysis of the most Visibe Companies in the Scandinavian Coutries" Corporate Reputation Review Vol.7 No.3 PP. 218-230

Aydin S. \& Ozer G. (2004) "The Analysis of Antecedents of Customer loyalty in the Turkish Mobile Telecommunication Market”, European Journal of Marketing, vol.39, No. 7/8, PP.910925

Babbie R. E., (2005) "The Basics of Social Research" ISBN0534630367

Chu-Mei Liu, "The effects of promotional activities on brand decision in the cellular telephone industry", Journal of Product and Brand Management, Vol. 11 No.1 2002, PP. $42-51$

Colin Jevons, (2005) "Beyond Products brand management" Journal of Product and Brand Management, Vol14 No.2, PP.117118

Daly, L. J. (2002), "Pricing for profitability", John Wiley \& Sons, Inc ISBN: 0471415359

"Economic Impact of mobile communications in Serbia, Ukraine, Malaysia, Thailand, Bangladesh and Pakistan" (2008), A report for Telenor ASA 13/02/2008 by Deloitte \& Touche LLP(private and confidential report).

Einwilles S. \& Will M., (2002) "Towards an integrated approach to corporate branding" An International Journal Vol.7 No.2 PP.100109

Emory W. C., \& Cooper R. D., (1991), "Business Research Methods" 4th Edition, ISBN-0-256-09265-6

Fifield, P. (1998) "Marketing strategy", 2nd edition ISBN 07506 32844

Ganesan S. (1994) "Determination of Long-term Orientation in the Buyer-seller Relationships" Journal of Marketing, 58/2 ABI/INFORM

Giden, R. 1993, "The Name game”, Cheers, PP.59-62

Gorard S., (2001)., "Quantitative Methods in Educational Research" Edition one ISBN 0-8264-5307-4

Gustafsson A. Roos I. \& Edvardsson B., (2003) "Customer Club in a Relationship Perspective: A Telecom Case" Managing Service Quality Vol.14, No.2/3 PP.157-168
Gylling C. \& Lindberg-Repo K. (2006), "Investigating the Links Between Corporate Brand and a Customer Brand" Journal of Brand Management Vol. 13 No. 4/5 PP.257-267

Johnson C. W., Sirikit A., (2002), "Service Quality in the Thai Telecommunication Industry: A tool for achieving a sustainable competitive advantage" Management Decision, 40/7 PP.693-701

Joseph Arthur Rooney, (1995) "Branding: a trend for today and tomorrow", Journal of Product and Brand Management, Vol. 4 No. 4 PP. $48-55$

Karine, M. E., Frank, L. \& Laine, K. (2004), Effect of price on the diffusion of cellular subscriptions in Finland, Journal of product and Brand management, Vol. 13 No. 3, pp. 192-199

Kay J. M., (2006) "Strong Brands and Corporate Brands" European Journal of Marketing Vol.40 No.7/8 PP. 742-760

Kotler, P., Armstrong, G., Saunders, J. and Wong, V. (1996), Principles of Marketing: The European Edition, Prentice-Hall, Hemel Hempstead.

Kotler P., Armstrong G., Saunders J., Wong V., (1999) "Principles of Marketing" (2nd Edition) Europe Prentice Hall Edition.

Kotler P., 1994 "Marketing Management" Prentice Hall International ISBN 0-13-098005-6

Laforet, S. and Saunders, J. (1994), "Managing brand portfolios: how the leaders do it", Journal of Advertising Research, Vol. 34 No. 5, pp. 64-7.

Leisen B., Vance C., (2001) "Cross national assessment of Services Quality in Telecommunication Industry: Evidence from USA and Germany" Managing Service Quality Vol.11 N0.5 PP.307-317

Lindmark S., Andersson J. E., Bohlin E., Johansson M., (2006), "Innovation System Dynamics in the Swedish Telecom Sector" Emerald Group Publishing, Vol.8 No.4 PP49-66 ISSN 1463-6697

Lisa Wood, "Brand and Brand Equity: Definition and Management" Journal of Management Decision, 38/9, 2000 PP. 662-669.

O'Loughlin D., Szmigin I. \& Turnbull P. (2004), "Branding and Relationships: Customer and Supplier Perspective" Journal of Financial Service Marketing Vol. 8 No.3 PP. 218-230

Maruzzelli G. (2005) “Investing in Serbia's Internet and IT Sector: Challenges and Opportunities" (Public Report)

Maxwell J. A. (1996), "Qualitative design research" Sage publications applied Social research Methods series Vol. 41 ISBN 0-8039-738-2

Mcnabb E. D., (2002), "Research Methods in Public Administration and nonprofit Management", ISBN-0765609576

Munnukka T. (2005), "Dynamics of Price Sensitivity Among Mobile Service Customers" Journal of Product and Brand Management, 14/1, PP. 65-75

Oulton T. (1995), "Management Research for information" Management Decision, Vol.33 No.5 PP.63-67

Ozer G., Aydin S., Arasil O. (2005) " Customer Loyalty and Effect of Switching Costs as a Moderator Variable" Marketing Intelligence and Planning Vol.23 No.1 PP. 89-103

Parry C. (1998), "Process of a case study methodology for post graduate research in marketing" European Journal of Marketing Vol. 32 No. 9/10 PP. 785-802

Ranaweera C. Prabhu J. (2003), "The Influence of Satisfaction, Trust and Switching barriers on customer retention in a continuous purchasing setting" International Journal of Service Industry Management Vol.14 No.4 PP. 374-395 
Remenyi D., Money A., Williams B., Swartz E., (1998) "Doing research in Business and Management: An introduction to process" Sage Publication, ISBN- 0761959505

Riezebos R. Brand management, 2003, FT Prentice Hall ISBN 0273-65505-1

Saunders J. and Guoqun Fu., 1997, “Journal of Product and Brand Management" Vol. 6, No.1 PP.40-48

Schultz M. Antorini M.Y, Csaba F.F “Corporate Branding, Purpose/People/Process" Copenhagen Business School Press, 2005. ISBN: 8763001403

Shi, M., Chiang, J. and Duk Rhee, B. (2006), "Price competition with reduced consumer switching costs", Management science, Vol. 52, No.1, pp. 27-38

Souiden N. Kassim M. N. Hong Ja. H., 2005, " The effect of corporate branding dimensions on consumer's product evaluation" European Journal of Marketing Vol. 40 No. 7/8 PP. 825-845

Uggla H., (2006), "The Corporate brand association base" European Journal of Marketing Vol.40 No.7/8 PP. 785-802

Uncles, M., Cocks, M. and Macrae, C. (1995), "Brand architecture: reconfiguring organisations for effective brand management", The Journal of Brand Management, Vol. 3 No. 2, pp. 1-12.

"Utilization of information and communication technologies in Serbia" (2008) by Serbian statistical office.

Venetis A. K. Ghauri N. P. (2004), "Service quality and customer retention; building long tem relationship" European journal of marketing, Vol. 38 No. 11/12, pp.1577-1598
Verikoukis Ch. and Angelidis P. (2006) "Mobile Telecommunications Landscape in Associate Candidate and Western Balkan Countries “

Xie Yu. H. Boggs D.J. (2006) "Corporate Branding versus Product Branding in emerging Markets" Marketing Intelligence and Planning, Vol.24 No.4, PP. 347-364

Yin Robert K. (1994), "Case study Research Design and Methods" 2nd edition, sage publications.

\section{Internet}

http://books.google.com/books?id=XvZ2o9FUuQ8C\&dq=corporat e+branding+history\&source $=$ gbs_summary_s\&cad $=0$ View on 15 Nov. 2008. 3:55 AM

www.bg.ac.yu

http://www.mts.telekom.rs/

www.telenor.com

www.telenor.rs

www.telekomunikacije.co.yu/mobilna/mts_cene.html

www.telekom.yu/

www.vipmobile.co.yu/

www.vodickrozbu.com/index_en.htm

www.vodiczabrucose.com/organizacije_en 